Mammadova Gulsum Mirdamad,

Ph.D., Azerbaijan State University of Economics, Azerbaijan

ORCID ID, 0000-0002-8797-5040

email: Gulsum.mammadova75@gmail.com

\title{
INNOVATIVE TOOLS FOR INVESTMENT MANAGEMENT IN THE DIGITAL ECONOMY: A GUIDE FOR POST-SOCIALIST COUNTRIES
}

Abstract. This paper summarizes the arguments and counterarguments within the scientific discussion on the issue of establishing the main factors that determine the parameters and dynamics of investment activity in the country based on sources of investment financing. The main purpose of the research is to study the formed in post-socialist countries features of investment management and to develop proposals for the introduction of innovative approaches to investment management considering the experience of developed countries and current trends in digitalization of the economy. Investigation of the topic of investment management in post-socialist countries in terms of resources of investment financing is carried out in the paper in the following logical sequence. First, the literature review and theoretical analysis of the issue allowed identifying the main sources of investment financing such as own funds of enterprises, household savings, banking sector loans, capital market financing, budget funds, foreign direct and portfolio investment, funds of international organizations. The second stage of the study held a comparative analysis of the role of each of the factors on the parameters and dynamics of investment activity in post-socialist countries. Methodological tools of the research methods are correlation and regression analysis. The statistical base of the study is the World Bank data on gross capital formation, gross savings, foreign direct and portfolio investment, long-term commercial bank loans, taxes on income, profit and capital gains. The third component of the research is the study of the experience of developed countries in the use of innovative investment financing tools, analysis of the dynamics of digital capital management tools such as WealthTech. Based on the study findings, the authors proposed recommendations for improving the efficiency of investment management in post-socialist countries and options for adapting digital tools to attract investment and manage them.

Keywords: digital capital management, financial innovation, gross capital formation, investment financing, WealthTech.

Introduction. In post-socialist countries, there are problems with the effective functioning of market mechanisms, raising, distributing and redistributing capital through the banking system, stock market and the use of market leverage. Therefore, in these countries, it is important to revive investment activity through government incentives, in the form of tax benefits, direct budget funding, as well as attracting targeted international assistance and loans from international organizations. At the same time, postsocialist countries lag behind developed countries not only in the level of development of the financial sector but also in the level of implementation of technological (FinTech) innovations and their varieties (e.g., WealthTech). Post-socialist countries are followers, i.e., they usually study and adopt the successful experience of more developed countries, as if constantly catching up with them in development (Borzenko, 2019). Given the lower level of development, the effectiveness of investment management in post-socialist countries is more critical. An element of modern investment management is the use of modern technological opportunities and innovations. If in developed countries new technologies are seen as complementary to traditional financial intermediaries, in developing countries such new technologies can not only complement but also compensate in some way for the absence or inefficiency of those mechanisms that should be represented by traditional market participants (Feher and Varga, 2019). The article aims to study the formed in post-socialist countries features of investment management and to develop proposals for the introduction of innovative approaches to investment management considering

Cite as: Mirdamad, M. G. (2020). Innovative Tools for Investment Management in the Digital Economy: a Guide for Post-Socialist Countries. Marketing and Management of Innovations, 4, 181-190. http://doi.org/10.21272/mmi.2020.4-14 
the experience of developed countries and current trends in digitalization of the economy. Thus, the structure of the article includes a theoretical study of the existing approaches to investment financing; empirical study of the impact of investment financing factors on gross capital formation and analysis of innovative investment management tools in terms of the possibility of their use in post-socialist countries to improve the efficiency of investment management and increase investment activity.

Literature Review. Characteristic of post-socialist countries is the violation of the evolutionary market development of the financial system and investment financing processes, which in the transition to a market economy required restructuring of the economy, privatization and several economic reforms. Today, the countries of this group continue to lag behind the developed countries in terms of economic development. One of such areas is investment and innovation development (Karmowska, 2017). Traditionally, the sources of investment financing include own funds of enterprises, household savings, banking sector loans, capital market financing, budget funds, foreign direct and portfolio investment, funds of international organizations (Aimurzina et al., 2019). The possibilities of using each of these sources in different countries have their own specifics. Still, at the same time, it could be identified certain patterns as the characteristics of post-socialist countries. Insufficient development of market mechanisms for financing investments, such as the banking system and the stock market, led to a predominance of own funds of enterprises in the structure of financing investments. At the same time, it stands to mention that most enterprises in the early stages of the transition to a market economy were unprofitable. Besides, nowadays, the vast majority of them remain inefficient and have limited resources to finance investment and innovation (Myant, 2015). In terms of studying the own funds of enterprises as a source of investment, it is essential to analyze the country's tax system. The level of taxation of profits and capital allows determining the share of profits that can be reinvested in production and, accordingly, the influence of tax incentives or restrictions on the investment activity of enterprises.

One of the main sources of investment resources in a normally functioning economy should be the savings of the population. Then they are redistributed through the banking system and the stock market between the recipients of the capital (borrowers and issuers). Individuals could participate in financing investments by operating in the stock market. Besides, they could form savings through banking institutions, private pension funds, insurance companies and other institutional investors who could make significant investments by accumulating small funds of individuals. In post-socialist countries, the availability of financial services and the development of the financial sector are the factors and limitations of the participation of individuals in investment activities. Given the lack of own financial resources and limited access to finance through bank loans or the stock market, a characteristic feature of post-socialist countries is the presence of a significant share of budget financing of investment projects and attracting funds from international organizations (Dudareva et al., 2017; Dykes et al., 2020). Most of the studied countries cooperate with international organizations and receive assistance from them for the development of infrastructure services, administrative reforms, state-owned enterprise restructuring and privatization, environmental policies, micro, small and medium enterprise support and more. In particular, the organizations that purposefully finance (provide loans) for investment projects are such organizations of the World Bank Group as the International Development Association (IDA), the International Bank for Reconstruction and Development (IBRD). At the same time, an increase in the level of digitalization and the introduction of information technology solutions in all economic processes characterize the modern development of the world economy (Neopulo et al., 2020). That also affected the investment sphere. The study and consideration of these aspects for post-socialist countries are important both for building a competitive and innovative economy, as well as the use of new FinTech solutions to create new opportunities and smooth out the shortcomings of the national economy.

Methodology and research methods. The ability to attract financial resources for investment activities from different sources determines the dynamics of the overall indicator of investment activity in 
the country. A dependent variable of this study is the indicator of gross capital formation, which consists of outlays on additions to the fixed assets of the economy plus net changes in the level of inventories.

The following indicators could be used as factor variables to analyze the dependence of gross capital accumulation on the parameters of the financial system and such sources of investment financing as own funds of enterprises, bank loans, foreign direct investment, stock market funding and international organizations funding: gross savings, foreign direct investment, long-term commercial bank loans, taxes on income, profit and capital gains, net financial flows received from international organizations, portfolio investment. The source of statistical data for the research is the open statistical database of the World Bank, namely the section World Development Indicators. To bring the indicators to a comparable form, they are presented as a percentage of the country's GDP (for the indicator taxes on income, profit and capital gains - as a percentage of revenue).

The study is conducted on the basis of 28 countries, including the countries of the former Soviet Union and European post-socialist countries.

The study period is 20 years: from 2000 to 2019 . The selected period is long enough to build correlation and regression relationships. At the same time, choosing a longer period for analysis may distort the results, as these are post-socialist countries that restructured their economies and only moved to a market economy in the 1990s.

Results. Although the selected sample consists of post-socialist countries, they are characterized by different levels of economic development, different regional affiliation. Moreover, they showed different dynamics of investment activity for the analyzed period 2000-2019. The group of studied countries includes both post-Soviet and post-socialist European countries. According to the indicator of the gross capital formation in 2019, there are no regional patterns in the dynamics of investment activity. The highest indicators of gross capital formation were in Uzbekistan, Northern Macedonia, Kyrgyzstan, Montenegro, Belarus, Hungary, Estonia, etc. By contrast, among the countries that had the lowest level of gross capital formation were Ukraine, Lithuania, Armenia, Bulgaria and Poland. Most of the surveyed countries showed positive indicators of average annual growth of gross capital. Herewith, the highest indicators of annual growth were in Tajikistan and Serbia. On the other hand, countries such as the Czech Republic, Albania, Slovakia, Slovenia, Poland, Armenia and Ukraine had a negative average annual growth in gross capital formation (Fig. 1). The presence of a stage of transition from a socialist to capitalist society and the restructuring of the economy is a common feature of the studied countries. However, the starting positions, as well as the chosen path of development of the countries, were different. Today they are at different levels of implementation of economic reforms, have differences in the development of the financial system (including indicators of the stock market, banking system, taxation system), indicators of living standards and other economic parameters (Brzezinski and Salach, 2020; Kalinkova, 2019; Mikiashvili and Karmowska, 2020). All these characteristics indirectly affect the indicator of gross capital formation (GCF), which was chosen as the main indicator of the level of investment activity in the country. The study presents a correlation-regression analysis for identifying the most significant parameters that affect the level of gross capital formation in each of the studied countries, . As factor (independent) variables are indicators that characterize certain aspects of the formation of sources of investment financing:

- $\quad \mathrm{GS}$ - gross savings, \% of GDP

- $\quad \mathrm{FDI}$ - foreign direct investments, net inflows, \% of GDP;

- TAX - taxes on income, profits and capital gains, $\%$ of revenue;

- $\quad$ BLT - long-term commercial bank loans, \% of GDP;

- $\quad$ IDA - net financial flows received from international organizations (IDA, IBRD), \% of GDP;

- $\quad \mathrm{PI}$ - portfolio investment (equity and debt securities), \% of GDP.

The analysis of the relationship between the indicator of gross capital formation and indicators that reflect the sources of investment capital is implemented in two stages. 
M. G., Mirdamad. Innovative Tools for Investment Management in the Digital Economy: a Guide for Post-Socialist Countries

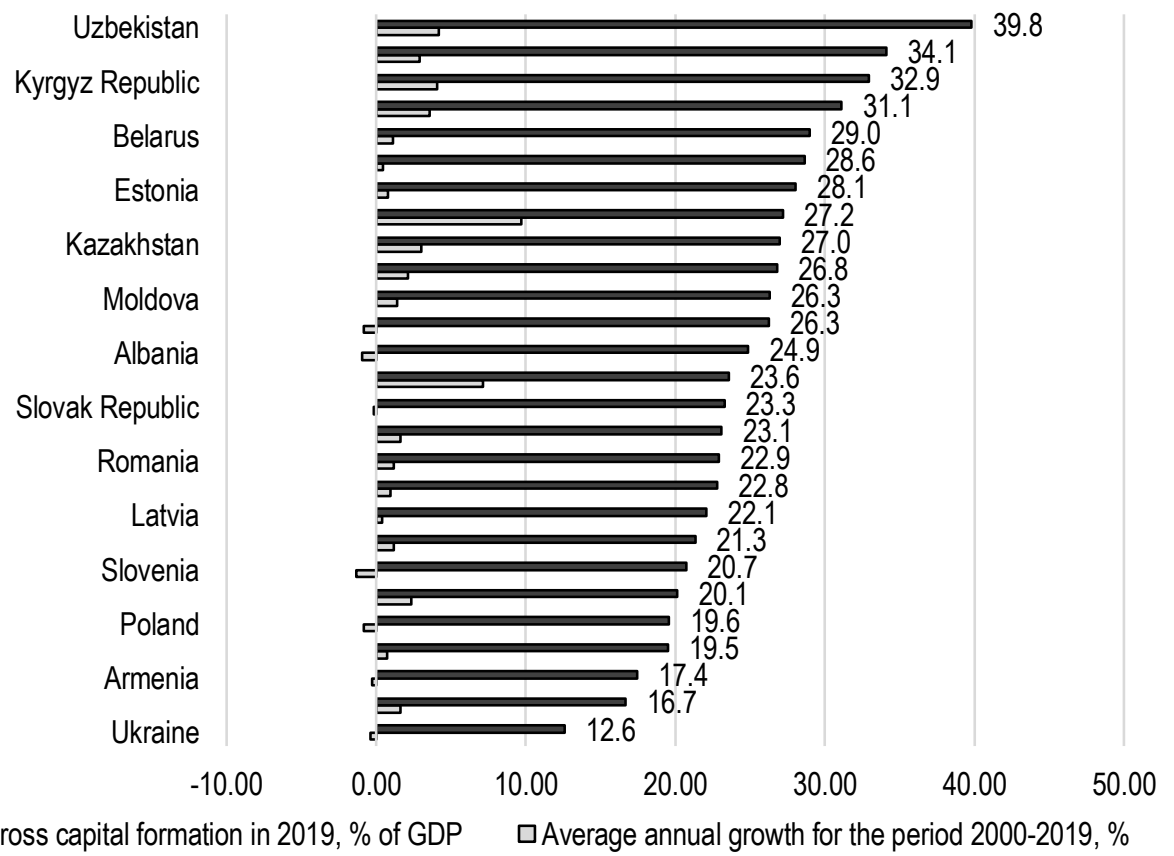

Figure 1. Gross capital formation in post-socialist countries in 2000-2019

Source: developed by the author based of (World Bank, 2020).

In the first step, the correlation analysis allowed identifying the relationship between each pair of variables. In the second step, the construction of regression models was conducted for those pairs of indicators with the detected presence of a significant correlation. Table 1 presents the results of correlation and regression analysis for each pair of parameters on the example of Azerbaijan.

Table 1. Detailed results of correlation and regression analysis (fragment, on the example of Azerbaijan)

\begin{tabular}{cccc}
\hline $\begin{array}{c}\text { Independent } \\
\text { variables }\end{array}$ & $\begin{array}{c}\text { Correlation } \\
\text { coefficient }\end{array}$ & Regression equation & $\mathbf{R}^{2}$ \\
\hline GS & -0.32 & $\mathrm{X}$ & $\mathrm{X}$ \\
FDI & $0.94^{*}$ & $\mathrm{GCF}=0.66 \cdot \mathrm{FDI}+17.43$ & $0.89^{*}$ \\
TAX & 0.43 & $\mathrm{X}$ & $\mathrm{X}$ \\
BLT & 0.11 & $\mathrm{X}$ & $\mathrm{X}$ \\
IDA & $0.64^{*}$ & $\mathrm{X}$ & $20.60 \cdot \mathrm{IDA}+23.40$ \\
PI & -0.02 & & $0.40^{*}$ \\
\hline
\end{tabular}

${ }^{*}$ significance $5 \%$

Sources: developed by the authors.

In Azerbaijan, there is a high level of correlation between gross capital formation and foreign direct investment (correlation coefficient is 0.94 ). The relationship between gross capital formation and net financial flows received from international organizations is statistically confirmed. However, they are weak in strength. At the same time, gross savings, tax rates and long-term bank loans do not correlate with 
M. G., Mirdamad. Innovative Tools for Investment Management in the Digital Economy: a Guide for Post-Socialist Countries

gross capital formation. That could indicate that obtaining long-term bank loans for investment projects in Azerbaijan is problematic. The lack of correlation with the gross savings is the evidence of the inefficient operation of the stock market and the banking system, the lack of redistribution of savings through the financial market. Table 2 summarizes the results of the conducted similar analysis for other sample countries.

Table 2. Summary results of correlation and regression analysis of factors influencing the gross capital formation

\begin{tabular}{|c|c|c|c|c|c|c|c|}
\hline Country & $\begin{array}{l}\text { Independent } \\
\text { variables* }\end{array}$ & $\begin{array}{l}\text { Correl. } \\
\text { coef. }\end{array}$ & $\mathbf{R}^{2}$ & Country & $\begin{array}{c}\text { Independe } \\
\text { nt } \\
\text { variables }\end{array}$ & $\begin{array}{l}\text { Correl. } \\
\text { coef. }\end{array}$ & $\mathbf{R}^{2}$ \\
\hline Albania & $\begin{array}{l}\text { GS } \\
\text { FDI } \\
\text { IDA }\end{array}$ & $\begin{array}{l}0.73 \\
-0.51 \\
0.54\end{array}$ & $\begin{array}{l}0.53 \\
0.27 \\
0.30\end{array}$ & Lithuania & $\begin{array}{l}\text { FDI } \\
\text { TAX }\end{array}$ & $\begin{array}{l}0.76 \\
0.63\end{array}$ & $\begin{array}{l}0.58 \\
0.39\end{array}$ \\
\hline Armenia & $\begin{array}{l}\text { GS } \\
\text { FDI } \\
\text { TAX }\end{array}$ & $\begin{array}{l}0.64 \\
0.88 \\
-0.82\end{array}$ & $\begin{array}{l}0.41 \\
0.77 \\
0.69\end{array}$ & Moldova & $\begin{array}{l}\text { GS } \\
\text { FDI } \\
\text { BLT }\end{array}$ & $\begin{array}{l}0.65 \\
0.77 \\
0.51\end{array}$ & $\begin{array}{l}0.43 \\
0.60 \\
0.26\end{array}$ \\
\hline Azerbaijan & $\begin{array}{l}\text { FDI } \\
\text { IDA }\end{array}$ & $\begin{array}{l}0.94 \\
0.64 \\
\end{array}$ & $\begin{array}{l}0.89 \\
0.40 \\
\end{array}$ & Montenegro & \multicolumn{3}{|c|}{ No significant results } \\
\hline Belarus & $\begin{array}{l}\text { GS } \\
\text { FDI }\end{array}$ & $\begin{array}{l}0.68 \\
0.61 \\
\end{array}$ & $\begin{array}{l}0.47 \\
0.38 \\
\end{array}$ & $\begin{array}{c}\text { North } \\
\text { Macedonia }\end{array}$ & $\begin{array}{l}\text { GS } \\
\text { IDA }\end{array}$ & $\begin{array}{c}0.88 \\
-0.70 \\
\end{array}$ & $\begin{array}{l}0.78 \\
0.49 \\
\end{array}$ \\
\hline $\begin{array}{l}\text { Bosnia \& } \\
\text { Herzegovina }\end{array}$ & $\begin{array}{c}\text { FDI } \\
\text { TAX } \\
\text { BLT } \\
\text { PI }\end{array}$ & $\begin{array}{c}0.71 \\
-0.69 \\
0.75 \\
-0.58\end{array}$ & $\begin{array}{l}0.51 \\
0.48 \\
0.57 \\
0.33\end{array}$ & Poland & $\begin{array}{l}\text { FDI } \\
\text { TAX }\end{array}$ & $\begin{array}{l}0.54 \\
0.66\end{array}$ & $\begin{array}{l}0.29 \\
0.44\end{array}$ \\
\hline Bulgaria & $\begin{array}{l}\text { GS } \\
\text { FDI } \\
\text { BLT }\end{array}$ & $\begin{array}{l}-0.61 \\
0.86 \\
0.87\end{array}$ & $\begin{array}{l}0.37 \\
0.73 \\
0.76\end{array}$ & Romania & \multicolumn{3}{|c|}{ No significant results } \\
\hline Croatia & $\begin{array}{l}\text { FDI } \\
\text { TAX }\end{array}$ & $\begin{array}{l}0.69 \\
0.62\end{array}$ & $\begin{array}{l}0.48 \\
0.39 \\
\end{array}$ & Russian Fed. & \multicolumn{3}{|c|}{ No significant results } \\
\hline Czech Rep. & $\begin{array}{c}\text { GS } \\
\text { FDI } \\
\text { TAX } \\
\text { PI }\end{array}$ & $\begin{array}{l}0.55 \\
0.52 \\
0.59 \\
0.53\end{array}$ & $\begin{array}{l}0.30 \\
0.27 \\
0.34 \\
0.28\end{array}$ & Serbia & $\begin{array}{l}\text { FDI } \\
\text { BLT }\end{array}$ & $\begin{array}{l}0.64 \\
0.73\end{array}$ & $\begin{array}{l}0.41 \\
0.53\end{array}$ \\
\hline Estonia & TAX & 0.60 & 0.37 & Slovak Rep. & $\begin{array}{l}\text { GS } \\
\text { FDI }\end{array}$ & $\begin{array}{l}0.48 \\
0.76\end{array}$ & $\begin{array}{l}0.23 \\
0.58 \\
\end{array}$ \\
\hline Georgia & $\begin{array}{c}\text { GS } \\
\text { TAX }\end{array}$ & $\begin{array}{c}0.55 \\
-0.52\end{array}$ & $\begin{array}{l}0.30 \\
0.27\end{array}$ & Slovenia & $\begin{array}{c}\text { GS } \\
\text { TAX }\end{array}$ & $\begin{array}{l}0.65 \\
0.92\end{array}$ & $\begin{array}{l}0.42 \\
0.84\end{array}$ \\
\hline Hungary & No signif & ant results & & Tajikistan & $\begin{array}{l}\text { BLT } \\
\text { IDA }\end{array}$ & $\begin{array}{c}0.50 \\
-0.73\end{array}$ & $\begin{array}{l}0.25 \\
0.53\end{array}$ \\
\hline Kazakhstan & BLT & 0.61 & 0.37 & Turkmenistan & FDI & 0.70 & 0.50 \\
\hline Kyrgyz Rep. & $\begin{array}{l}\text { BLT } \\
\text { IDA }\end{array}$ & $\begin{array}{l}0.50 \\
-0.70\end{array}$ & $\begin{array}{l}0.25 \\
0.49\end{array}$ & Ukraine & $\begin{array}{l}\text { GS } \\
\text { FDI } \\
\text { BLT }\end{array}$ & $\begin{array}{l}0.67 \\
0.61 \\
0.76 \\
\end{array}$ & $\begin{array}{l}0.45 \\
0.37 \\
0.57\end{array}$ \\
\hline Latvia & $\begin{array}{l}\text { FDI } \\
\text { TAX }\end{array}$ & $\begin{array}{l}0.75 \\
0.76\end{array}$ & $\begin{array}{l}0.56 \\
0.58\end{array}$ & Uzbekistan & $\begin{array}{l}\text { GS } \\
\text { FDI } \\
\text { IDA }\end{array}$ & $\begin{array}{l}0.88 \\
0.58 \\
0.62\end{array}$ & $\begin{array}{l}0.78 \\
0.34 \\
0.38\end{array}$ \\
\hline
\end{tabular}

* only significant results (significance $5 \%$ ).

Sources: developed by the authors. 
Table 2 shows that the main factors influencing the rate of gross capital formation are a foreign direct investment and gross savings. The analysis confirmed the existence of a strong direct link between gross capital formation and foreign direct investment for countries as follows: Armenia, Azerbaijan, Bulgaria, Latvia, Lithuania, Moldova, and Slovakia. For many other countries, the relationship between these parameters is moderate. That is because a shortage of domestic financial resources, the inflow of foreign capital for post-socialist countries is one of the main factors in their investment development. Portfolio investment did not show a strong correlation with the gross capital formation in any of the countries studied. Furthermore, a similar conclusion could be made for taxes on income, profits and capital gains. It showed a strong inverse correlation only in Armenia, and a strong direct correlation in Slovenia and Latvia. For some countries, there was a moderate correlation between gross capital formation and net financial flows received from international organizations (Kyrgyzstan, Tajikistan, Northern Macedonia). Long-term commercial bank loans can be identified as a factor of strong influence on gross capital formation only in Ukraine, Bulgaria, Serbia, Bosnia and Herzegovina.

Besides, the analysis confirmed the strong impact of gross savings on capital formation for postsocialist countries such as Albania, Northern Macedonia and Uzbekistan. However, for most countries, the impact of gross savings is moderate or low. In a developed economy, gross savings are the basic source of investment resources in the economy. The reasons for the low importance of gross savings in the formation of gross capital in most post-socialist countries are the following:

- low level of household income, which in turn leads to low levels of gross savings. In this case, the country could actively attract funding from international organizations;

- distrust to the financial sector due to insufficient level of legislation, government guarantees, investment protection, weakness of the banking system, frequent bankruptcies, insufficient capitalization, etc., as a result of which gross savings remain outside the financial system;

- the inefficiency of the stock market and the banking market, which could not provide the required level of redistribution of financial resources and does not use gross savings (deposits) to finance investment needs.

One of the alternatives to increase the efficiency of investment management and solve the problem of insufficient funds of individuals to finance investment projects is the use of new capital and investment management tools that have emerged and developed through digital technologies, namely WealthTech. On the one hand, these include investment tools that help potential investors (including individual investors) to select investment objects and make investments using capital management algorithms and programs. On the other hand, these tools could be used to attract corporate funding from investors, automate and optimize these processes (Ivanitsky and Samarukha, 2018; Khomenko and Ruzhnikov, 2019; Novick et al., 2016). In a broad sense, WealthTech management tools include a wide range of technological innovations related to investment, personal finance management, wealth and asset management. It is possible to distinguish such main categories of WealthTech innovations as roboadvising, digital brokers, micro-investing and portfolio management. Robo-advisors are automated applications based on artificial intelligence technologies, machine learning, big data and other technological innovations. They are designed to replace traditional investment advisers and help make independent investment decisions regarding savings, retirement plans, homeownership and others, considering the client's preferences, tolerable risk and other factors (Jung et al., 2018; Ludden et al., 2015). Digital brokers and online trading platforms combine a wide variety of online platforms, through which the user can get all the information about the stock market, compare different investment options, make investment transactions and more (D'Acunto et al., 2017). Micro-investing is also an online platform, the specificity of which for the individual investor is the possibility to make small investments without commission costs (Ruhr et al., 2019). Portfolio management tools also have the format of an online platform and allow an individual to combine all his investments and manage them from a single platform 
M. G., Mirdamad. Innovative Tools for Investment Management in the Digital Economy: a Guide for Post-Socialist Countries

(Kahn, 2018; Sotnyk et al., 2020). The considered innovative tools of investment management can provide several advantages for all participants of the capital market (Fig. 2).

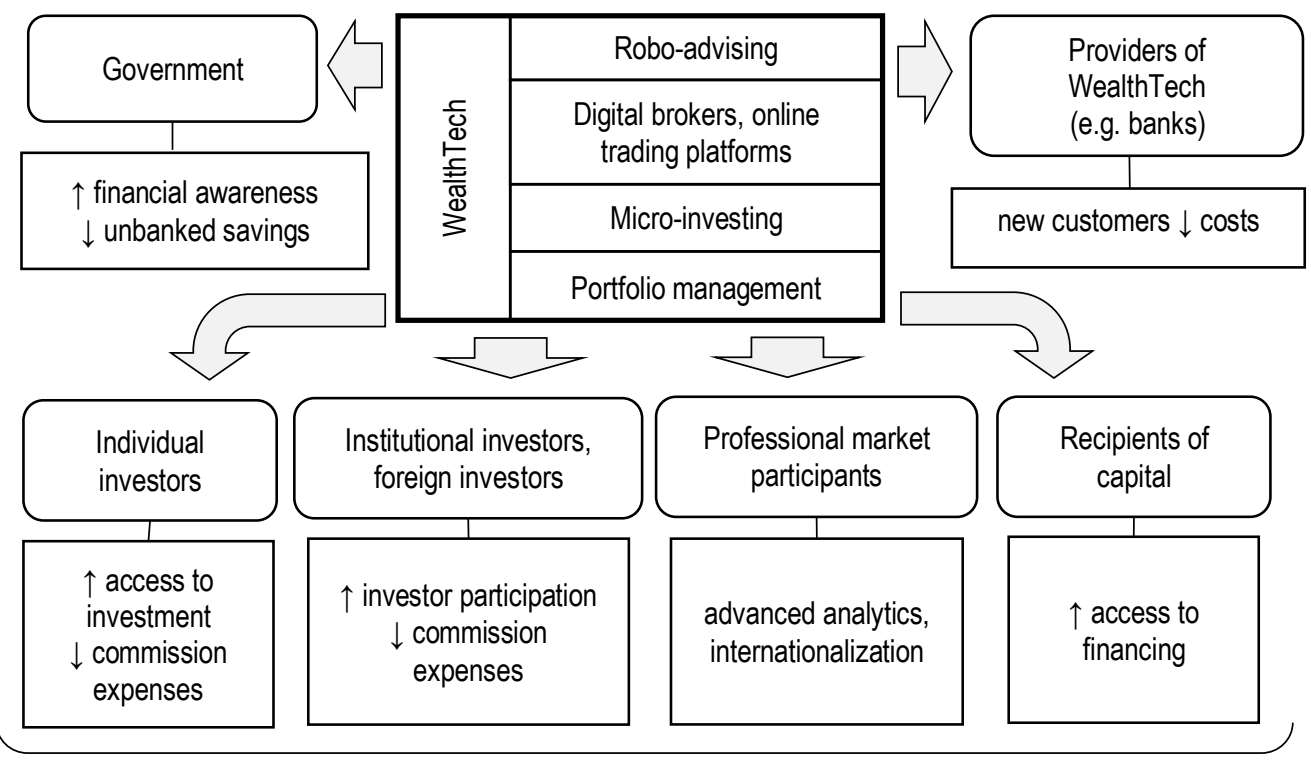

Developed synenergistic ecosystem of capital market

Figure 2. Benefits of innovative digital tools in investment management

Source: developed by the author based of (Harvey et al., 2017; Min and Azmel, 2017; von Nitzsch et al., 2017; Phoon and Koh, 2018; Valverde et al., 2020).

The findings of WealthTech analysis allowed concluding that the introduction and dissemination of these innovations in post-socialist countries will help correct shortcomings and mitigate the negative aspects of the capital market in these countries. Moreover, it will close gaps in access to investment services both from the standpoint of individual investors and recipients of capital. In particular, the considered WealthTech tools could increase the inclusion of individuals in the financial system, increase savings and capital market efficiency in general, form a comprehensive ecosystem. In turn, that ecosystem mentioned above will provide a synergistic effect and higher efficiency through better interaction between its participants. The use of robo-advising and online trading platforms, which contain a significant amount of investment information and allow to compare different investment options, create many opportunities in terms of public administration (Lin and Tjio, 2020). First of all, they bring together domestic and foreign investors, venture investors and micro-investors. Secondly, they accumulate information on active investment projects, the issue of securities (including over-the-counter) and create opportunities for raising financial awareness, placement and promotion of useful reference and educational information (Taffler, 2017). At the present stage, the share of individuals who prefer independent investment decisions is growing. Researchers explain this by the growing share of millennials in the structure of the economically active population. For these categories of people, the use of robo-advising is an option to involve them in the financial system if they do not trust traditional financial intermediaries or do not want to use their services, or for other reasons do not have access to these services (Agarwal et al., 2017; Beltramini, 2018). Banks and other financial intermediaries that are beginning to develop WealthTech in their structures (create a robo-advising option or start their own investment or micro-investment online 
platforms) will be able to gain access to new clients and minimize their costs by switching to roboconsulting. In post-socialist countries, there are examples of the existence of online investment platforms, robo-advising, micro-investing and portfolio management tools. Such successful examples can be found in relatively more developed countries and with a higher level of digitalization (in the Czech Republic, Poland, Slovenia, etc.). At the same time, these are only isolated cases. Investments in WealthTech development in post-socialist countries are meager. State-level support is needed to implement WealthTech (Vishnivetskaya and Ablyazov, 2020). For example, in the UK, the development of FinTech and WealthTech in particular, is supported by significant government funding (Vincent et al., 2015). Given this, there is a recommendation for post-socialist countries to form a centralized online investment platform that could create an ecosystem for investment market participants to unite them, ensure the exchange of information and services on micro-investment, portfolio management and more. Another important role of the state in this context is to provide information support for online platforms and increase financial awareness of participants.

Conclusions. The article analyzes the influence of factors on the indicator of gross capital accumulation based on sources of investment resources formation. Correlation and regression analysis showed that in post-socialist countries, gross capital formation is most closely linked to foreign direct investment. At the same time, gross savings tend to have a moderate or low impact on gross capital formation, due to the inefficiency of the financial sector and low incomes in most post-socialist countries. For increasing the efficiency of investment management and the involvement of individuals in investment activities, the introduction of innovative investment management tools, in particular WealthTech, is proposed. It is substantiated that the application of WealthTech would achieve several benefits for all market participants and ensure the development of a synergistic ecosystem in the capital market. Therefore, the state should support the development of WealthTech in post-socialist countries both in terms of creating an environment for the development of WealthTech and direct government funding.

Funding: This research received no external funding.

\section{References}

Agarwal, S., Chomsisengphet, S., \& Lim, C. (2017). What shapes consumer choice and financial products? A Review. Annual Review of Financial Economics, 9, 127-146. [Google Scholar] [CrossRef]

Aimurzina, B., Kamenova, M., Omarova, A., Bodaubayeva, G., Dzhunusova, A., \& Kabdullina, G. (2019). Major sources of financing investment projects. Entrepreneurship and Sustainability Issues, 7(2), 1555-1566. [Google Scholar] [CrossRef]

Baranovskyi, O. I. (2020). Regulation of functional and structural transformational processes in the financial sector. Financial and credit activity: problems of theory and practice, 1(32), 292-306. [Google Scholarl [CrossRef]

Baranovskyi, O. I. (2018). Quality of the transformational processes in the financial sector of the national economy: vectors of the measurement. Financial and credit activity: problems of theory and practice, 3(26), 350-367. [Google Scholar] [CrossRef]

Beltramini, E. (2018). Human vulnerability and robo-advisory: An application of Coeckelbergh's vulnerability to the machinehuman interface. Baltic Journal of Management, 13(2), 250-263. []Google Scholar [CrossRef]

Boiarko, I. M. (2016). Praxeological and situational approaches in the formation of strategic accounting. Financial and credit activities: problems of theory and practice, 2(21), 80-90. [CrossRef]

Borzenko, O. (2019). Imperatives of development of post-socialist countries financial markets. University Economic Bulletin, (43), 80-88. [Google Scholar] [CrossRef]

Brzezinski, M., \& Salach, K. (2020). Why Wealth Inequality Differs Between Post-Socialist Countries? SSRN Electronic Journal. [Google Scholar] [CrossRef]

Carbó-Valverde, S., Cuadros-Solas, P. J., \& Rodríguez-Fernández, F. (2020). The Effect of Banks' IT Investments on the Digitalization of their Customers. Global Policy, 11(1), 9-17. [Google Scholar] [CrossRef]

D’Acunto, F., Prabhala, N., \& Rossi, A. (2017). The Promises and Pitfalls of Robo-Advising. In 8th Miami Behavioral Finance Conference. [Google Scholar] [CrossRef]

Dudareva, A. B., Polyakova, A. A., \& Sidorin, A. A. (2017). Problems of financing investment processes using foreign capital. Russian Journal of Agricultural and Socio-Economic Sciences, 63(3), 42-52. [Google Scholar] [CrossRef]

Dykes, B. J., Stevens, C. E., \& Lahiri, N. (2020). Foreignness in public-private partnerships: The case of project finance investments. Journal of International Business Policy, 3(2), 183-197. [Google Scholar] [CrossRef] 


\section{G., Mirdamad. Innovative Tools for Investment Management in the Digital Economy: a Guide for Post-Socialist}

Countries

Feher, P., \& Varga, K. (2019, August). Identifying digital investing services using design thinking methodology. In 201913 th International Conference on Software, Knowledge, Information Management and Applications (SKIMA) (pp. 1-8). IEEE. [Google Scholar] [CrossRef]

Graczyk, A. M., Graczyk, A., \& Żołyniak, T. (2020). System for Financing Investments in Renewable Energy Sources in Poland. In Finance and Sustainability (pp. 153-166). Springer, Cham. [Google Scholar] [CrossRef]

Harvey, C. R., Rattray, S., Sinclair, A., \& Van Hemert, O. (2017). Man vs. Machine: Comparing Discretionary andSystematic Hedge Fund Performance. The Journal of Portfolio Management, 43(4), 55-69. [Google Scholar] [CrossRef]

Hrytsenko, L. L., Roienko, V., \& Boiarko, I. M. (2018). Institutional background of the role of state in investment processes activation. Financial and credit activities: problems of theory and practice, 1(24), 338-344. [CrossRef]

Ivanitsky, V. P., \& Samarukha, V. I. (2018). Transformation of the finance-investment mechanism at the sixth technological wave. Journal of New Economy, 19(6), 62-75. [Google Scholar] [CrossRef]

Jung, D., Dorner, V., Glaser, F. \& Morana, S. (2018). Robo-Advisory: Digitalization and Automation of Financial Advisory. Business \& Information Systems Engineering, 60(3). [Google Scholar] [CrossRef]

Kahn, R. N. (2018). The Future of Investment Management. CFA Institute Research Foundation Publications, November. [Google Scholar] [CrossRef]

Kalinkova, S. (2019). Measuring the competitiveness of post-socialist countries. University Economic Bulletin, 41, 90-98. [Google Scholar] [CrossRef]

Karmowska, G. (2017). Sustainable Growth of Societies in Post-Socialist Countries. Folia Pomeranae Universitatis Technologiae Stetinensis. Oeconomica, (89), 43-54. [Google Scholar] [CrossRef]

Khomenko, V. V., \& Ruzhnikov, E. A. (2019, October). Impact of the Digital Economy on Investment Projects. In Proceedings of the 2019 International SPBPU Scientific Conference on Innovations in Digital Economy (pp. 1-7). [Google Scholar] [CrossRef]

Kuznyetsova, A. Y., \& Klishchuk, O. V. (2017). Theoretical conception of price stability targeting arrangement: investigation of basic principles of implementation monetary regime. Financial and credit activity: problems of theory and practice, 2(23), 388-396. [Google Scholar] [CrossRef]

Lin, L., \& Tjio, H. (2020). Alternative Investments, Sustainability in the Digital Age. European Business Organization Law Review, 21(1), 1-5. [CrossRef]

Ludden, C., Thompson, K., \& Mohsin, I. (2015). The rise of robo-advice. Changing the concept of wealth management. Edited by Accenture Research. Retrieved from [Link]

Mikiashvili, N., \& Karmowska, G. (2019). The Development of Georgia and Poland Compared to Other Post-Socialist Countries. Folia Pomeranae Universitatis Technologiae Stetinensis. Oeconomica, (94), 43-58. [Google Scholar] [CrossRef] Min, C. W., \& Azmel, A. (2017). Developing a Facilitative Ecosystem for Digital Innovation in the Malaysian Capital Market. Nomura Journal Of Asian Capital Markets, 2(1), 14-18. Retrieved from [Link]

Myant, M. (2015). Varieties of capitalism in post-socialist countries. In Palgrave dictionary of emerging markets and transition economics (pp. 133-152). Palgrave Macmillan, London. [Google Scholar] [CrossRef]

Neopulo, K., Popov, I., \& Kuksov, A. (2020). Trends and prospects for the implementation of crowdfunding as a way of financing investment projects in Russia. Vestnik Universiteta, 1, 129-136. [CrossRef]

Novick, B., Lu, B., Fortin, T., Hafizi, S., Parkes, M., \& Barry, R. (2016). Digital Investment Advice: Robo Advisors Come Of Age. Viewpoint, BlackRock. Retrieved from [Link]

Phoon, K., \& Koh, F. (2017). Robo-advisors and wealth management. The Journal of Alternative Investments, 20(3), 79-94 [Google Scholar] [CrossRef]

Rekunenko, I. I., Hrytsenko, L. L., Boiarko, I. M., \& Kostyrko, R. A. (2019). Financial debt market in the system of indicators of development of the economy of the country. Financial and credit activities: problems of theory and practice, 2(29), 430-439.

Ruhr, A., Streich, D., Berger, B., \& Hess, T. (2019). A Classification of Decision Automation and Delegation in Digital Investment Management Systems. In Proceedings of the 52nd Hawaii International Conference on System Sciences. [Google Scholar] [CrossRef]

Sotnyk, I., Zavrazhnyi, K., Kasianenko, V., Roubík, H., \& Sidorov, O. (2020). Investment Management of Business Digital Innovations. Marketing and Management of Innovations, 1, 95-109. [Google Scholar] [CrossRef]

Taffler, R. (2018). Emotional finance: investment and the unconscious. The European Journal of Finance, 24(7-8), 630-653.

[Google Scholar] [CrossRef]

The World Bank (2020). DataBank. World Development Indicators. Retrieved from [Link]

Vincent, G., Laknidhi, V., Klein, P., \& Gera, R. (2015). Robo-advisors: capitalizing on a growing opportunity. Journal of Research on Robo Advisor Technology, 2. Retrieved from [Link]

Vishnivetskaya, A., \& Ablyazov, T. (2020). Improving state regulation of the digital transformation in the investment and construction sector. IOP Conference Series: Materials Science and Engineering, 940(1). [Google Scholar] [CrossRef]

von Nitzsch, R., Braun, D., \& Bons, R. W. (2017). Success Factors for Effective Customer Interaction in Digital Sales: A Case from the Digital Investment Service Industry. In Bled eConference (p. 7). [Google Scholar] [CrossRef]

Vovchak, O. D., Senyshch, P. M., \& Melnyk, T. V. (2019). «Purging» of the banking system: impacton the key performance indicators of banks. Financial and credit activity: problems of theory and practice, 1(28), 16-25. [Google Scholar] [CrossRef] 
M. G., Mirdamad. Innovative Tools for Investment Management in the Digital Economy: a Guide for Post-Socialist Countries

Маммедова Гюльсум Мірдамед гизи, PhD, доцент, Азербайджанський державний економічний Університет, Азербайджан

Інноваційні інструменти управління інвестиціями в цифровій економіці: рекомендації для постсоціалістичних країн

у статті систематизовано аргументи та контраргументи щодо визначення основних фракторів впливу на параметри та динаміку інвестиційної діяльності в постсоціалістичних країнах на основі аналізу джерел фрінансування інвестицій. Основною метою є дослідження особливостей управління інвестиційною діяльністю в постсоціалістичних країнах та розроблення пропозицій щодо впровадження інноваційних підходів до управління інвестиціями на основі досвіду розвинених країн та сучасних тенденцій иифровізації економіки. Методологічним інструментарієм проведеного дослідження є методи статистичного, кореляційного та регресійного аналізу. Статистичною базою є дані Світового банку щодо показників валового капіталу, валових заощаджень, прямих іноземних та портфельних інвестицій, довгострокових позик комериійних банків, оподаткування прибутку та капіталу. Для досягнення поставленої мети дослідження теми управління інвестиціями в постсоціалістичних країнах з точки зору формування джерел фрінансування інвестицій і ступеня їх важливості для нагромадження капіталу проводиться в наступній логічній послідовності. Поперше, проведено огляд наукових джерел та здійснено теоретичний аналіз досліджуваної проблематики для визначення основних джерел інвестиційного фрінансування, таких як власні кошти підприємств, заощадження домогосподарств, позики банківського сектору, отримання фрінансування на фондовому ринку, бюджетне фінансування, прямі іноземні та портфельні інвестиції, кошти міжнародних організацій. На другому етапі проведено порівняльний аналіз ролі кожного фактору у параметрах та динаміці інвестиційної активності в постсоиіалістичних країнах. Третім етапом дослідження $\epsilon$ вивчення досвіду розвинених країн щодо використання інноваційних інструментів ффінансування інвестицій. Автор проаналізував динаміку розвитку цифрових інструментів управління капіталом на прикладі WealthTech. За результатами проведеного дослідження ссформовано рекомендації щодо підвищення ефективності управління інвестиціями в постсоціалістичних країнах та варіанти адаптації цифрових інструментів для залучення інвестицій та управління ними.

Ключові слова: валові інвестиції, фінансові інновації, фінансування інвестицій, цифрові інструменти управління капіталом, WealthTech.

Manuscript received: 21.01.2020

(c) The author(s) 2020. This article is published with open access at Sumy State University 